\title{
The clinical importance of cardiopulmonary exercise testing and aerobic training in patients with heart failure
}

\author{
A importância clínica de testes de exercícios cardiopulmonares e treinamento \\ aeróbico em pacientes com insuficiência cardíaca
}

Arena R', Myers J $^{2}$, Guazzi $M^{3}$

\begin{abstract}
Introduction: The appropriate physiological response to an acute bout of progressive aerobic exercise requires proper functioning of the pulmonary, cardiovascular and skeletal muscle systems. Unfortunately, these systems are all negatively impacted in patients with heart failure $(\mathrm{HF})$, resulting in significantly diminished aerobic capacity compared with apparently healthy individuals. Cardiopulmonary exercise testing (CPX) is a noninvasive assessment technique that provides valuable insight into the health and functioning of the physiological systems that dictate an individual's aerobic capacity. The values of several key variables obtained from CPX, such as peak oxygen consumption and ventilatory efficiency, are often found to be abnormal in patients with HF. In addition to the ability of CPX variables to acutely reflect varying degrees of pathophysiology, they also possess strong prognostic significance, further bolstering their clinical value. Once thought to be contraindicated in patients with $\mathrm{HF}$, participation in a chronic aerobic exercise program is now an accepted lifestyle intervention. Following several weeks/months of aerobic exercise training, an abundance of evidence now demonstrates an improvement in several pathophysiological phenomena contributing to the abnormalities frequently observed during CPX in the HF population. These exercise-induced adaptations to physiological function result in a significant improvement in aerobic capacity and quality of life. Conclusions: Furthermore, there is initial evidence to suggest that aerobic exercise training improves morbidity and mortality in patients with HF. This paper provides a review of the literature highlighting the clinical significance of aerobic exercise testing and training in this unique cardiac population.
\end{abstract}

Key words: ventilatory expired gas; cardiac output; skeletal muscle; survival.

\section{Resumo}

Introdução: A resposta fisiológica aguda ao exercício aeróbio progressivo demanda funcionamento adequado dos sistemas pulmonares, cardiovasculares e músculo-esquelético. Infelizmente, todos estes sistemas estão negativamente afetados em pacientes com insuficiência cardíaca (IC), resultando numa redução significativa da capacidade aeróbia comparada com indivíduos aparentemente saudáveis. O teste de exercício cardiopulmonar (TCP) representa uma técnica não-invasiva de avaliação que fornece compreensão valiosa sobre a saúde e funcionamento dos sistemas fisiológicos que ditam a capacidade aeróbia de um indivíduo. Os valores de várias variáveis-chave obtidas através do TCP, como consumo pico de oxigênio e eficiência ventilatória são encontrados frequentemente como anormais em pacientes com IC. Além da capacidade das variáveis do TCP refletir de maneira aguda os graus variáveis da fisiopatologia, também possuem forte significância prognóstica, aumentando ainda mais o seu valor clínico. A participação num programa de exercícios aeróbios crônicos, anteriormente era contraindicada em pacientes com IC. Agora é uma intervenção aceitável de estilo de vida. Após um período de treinamento com exercícios aeróbios, durante várias semanas/meses, tem sido evidenciada uma melhora em vários fenômenos fisiopatológicos que contribuem às anormalidades constatadas frequentemente durante TCP na população com IC. Conclusões: As adaptações fisiológicas induzidas por exercícios aeróbios resultam em uma melhora significativa de capacidade aeróbia e de qualidade de vida. Além disso, há evidências sugerindo que treinamento com exercícios aeróbios melhora a morbidade e a mortalidade em pacientes com IC. Este artigo fornece uma revisão da literatura que destaca a significância clínica dos testes de exercícios aeróbios e treinamento nesta população cardíaca única.

Palavras-chave: gás expirado ventilatório; rendimento cardíaco; músculo esqueleto; sobrevivência

\section{Recebido: 15/01/2008 - Revisado: 17/01/2008 - Aceito: 04/02/2008}

'Departments of Internal Medicine, Physiology and Physical Therapy, Virginia Commonwealth University, Health Sciences Campus, Richmond, Virginia, United States ${ }^{2}$ VA Palo Alto Health Care System, Cardiology Division, Stanford University, Palo Alto, California, United States

${ }^{3}$ Cardiopulmonary Laboratory, Cardiology Division, University of Milan, San Paolo Hospital, Milan, Italy

Correspondence to: Ross Arena, PT, PhD, Associate Professor, Department of Physical Therapy, Box 980224, Virginia Commonwealth University, Health Sciences Campus, Richmond, VA, USA 23298-0224, e-mail: raarena@.vcu.edu 


\section{Introduction $: \because$.}

\section{Systems influencing the physiological response to normal exercise}

An individual's capacity to perform aerobic exercise is dependent upon pulmonary, cardiovascular and skeletal muscle function. While proper physiological functioning of these three systems is important, cardiac output (Q), i.e. the product of heart rate and stroke volume, is the primary determinant of peak or maximal oxygen consumption $\left(\mathrm{VO}_{2}\right)$. Cardiac output is approximately five liters/minute at rest and increases to approximately 20-25 and 30-35 liters/minute at maximal exercise in apparently healthy sedentary subjects and elite athletes, respectively. The ability of skeletal muscle to increase oxygen extraction during aerobic exercise plays a lesser but still important role in determining aerobic capacity. In apparently healthy subjects, the difference in oxygen $\left(\mathrm{O}_{2}\right)$ concentration between arterial and venous blood ( $\mathrm{a}-\mathrm{vO}_{2}$ diff) increases from approximately $5 \mathrm{mlO}_{2} / 100 \mathrm{ml}$ at rest to $16 \mathrm{mlO}_{2} / 100 \mathrm{ml}$ at maximal exercise. The Fick equation, defined as the product of $\mathrm{Q}$ and $\mathrm{a}-\mathrm{vO}_{2}$ diff, is used to describe $\mathrm{VO}_{2}$. While pulmonary function is not included in the Fick equation, the ability to increase gas exchange (oxygen intake and carbon dioxide removal) is of paramount importance to aerobic exercise capacity. Minute ventilation(VE), the product of respiratory rate and tidal volume, normally increases 10-20 fold at maximal aerobic exercise compared with resting values. It should be noted that pulmonary function is not typically the primary limiter of aerobic capacity, either in apparently healthy individuals or among patients diagnosed with cardiovascular disease. Even when the pulmonary, cardiovascular and skeletal muscle systems are all functioning properly, maximal aerobic capacity remains a rather heterogeneous phenomenon, since it is also influenced by age, sex, genetic predisposition and exercise habits. Considering these factors, the approximate range for maximal $\mathrm{VO}_{2}$ in the apparently healthy population is between $20-55 \mathrm{mlO}_{2} \cdot \mathrm{kg}^{-1} \cdot \mathrm{min}^{-1(1)}$.

\section{Pathophysiological abnormalities associated with diminished aerobic capacity in patients with heart failure}

Severely compromised cardiac function is a primary pathophysiological component in heart failure (HF), and previous investigations have demonstrated a significant relationship between cardiac output during exercise and peak $\mathrm{VO}_{2}$ in this population ${ }^{2-5}$. It has furthermore been well established that patients with HF frequently present reduced capillary density ${ }^{6}$ and intrinsic skeletal muscle abnormalities, primarily in the form of diminished aerobic (mitochondrial) function ${ }^{6-13}$. Given that aerobic capacity is reliant primarily on Q and secondarily on the a-vO diff, as defined by the Fick equation, the significant reduction in peak $\mathrm{VO}_{2}$ frequently observed in patients with $\mathrm{HF}$ should be of no surprise. On average, peak $\mathrm{VO}_{2}$ is approximately $50 \%$ lower in this patient population, compared with values observed in apparently healthy individuals matched according to age and sex. Moreover, peak $\mathrm{VO}_{2}$ is approximately $25 \%$ lower in patients with HF, compared with patients diagnosed with coronary artery disease ${ }^{14}$.

A relationship between pulmonary abnormalities and peak $\mathrm{VO}_{2}$ has also been demonstrated in patients with $\mathrm{HF}^{15-17}$. Both resting ${ }^{15}$ and maximal ${ }^{16}$ measures of pulmonary function (i.e. inspiratory capacity), as well as diffusion capacity ${ }^{17}$, have all demonstrated significant correlations with peak $\mathrm{VO}_{2}$. The degree to which these pulmonary abnormalities contribute towards the diminished aerobic capacity observed in HF, after accounting for the contributions of cardiovascular and skeletal muscle dysfunction, is unknown.

Figure 1 illustrates the systems involved in the physiological response to aerobic exercise and how HF affects these systems.

\section{The clinical applications of cardiopulmonary exercise testing in patients with heart failure}

Cardiopulmonary exercise testing (CPX) is a highly reliable ${ }^{18}$, well-accepted assessment technique in the HF population. American ${ }^{19-21}$ and European ${ }^{22-24}$ associations have endorsed its use. CPX is most often performed on a treadmill or lowerlimb ergometer using highly conservative ramping protocols, which are appropriate given the severely diminished exercise tolerance often observed in this population ${ }^{25,26}$. The addition of ventilatory expired gas analysis to the standard exercise test enables measurement of $\mathrm{VO}_{2}$, carbon dioxide production $\left(\mathrm{VCO}_{2}\right)$ and minute ventilation (VE) over time. In addition to aerobic capacity, several other variables generated from CPX data have demonstrated clinical value with regard to exercise prescription, prognosis and response to a given intervention. Table 1 highlights key considerations for several CPX variables in patients with HF, which are described in greater detail in the following sections. It should be noted that the overwhelming majority of the literature cited in subsequent sections consists of studies performed on systolic HF cohorts. While the initial evidence indicates that CPX is also prognostic in patients with diastolic $\mathrm{HF}^{27}$, much more work is required in this area. Therefore, with regard to the prognostic applications of CPX, the following information and recommendations primarily apply to patients diagnosed with systolic HF at this time. 


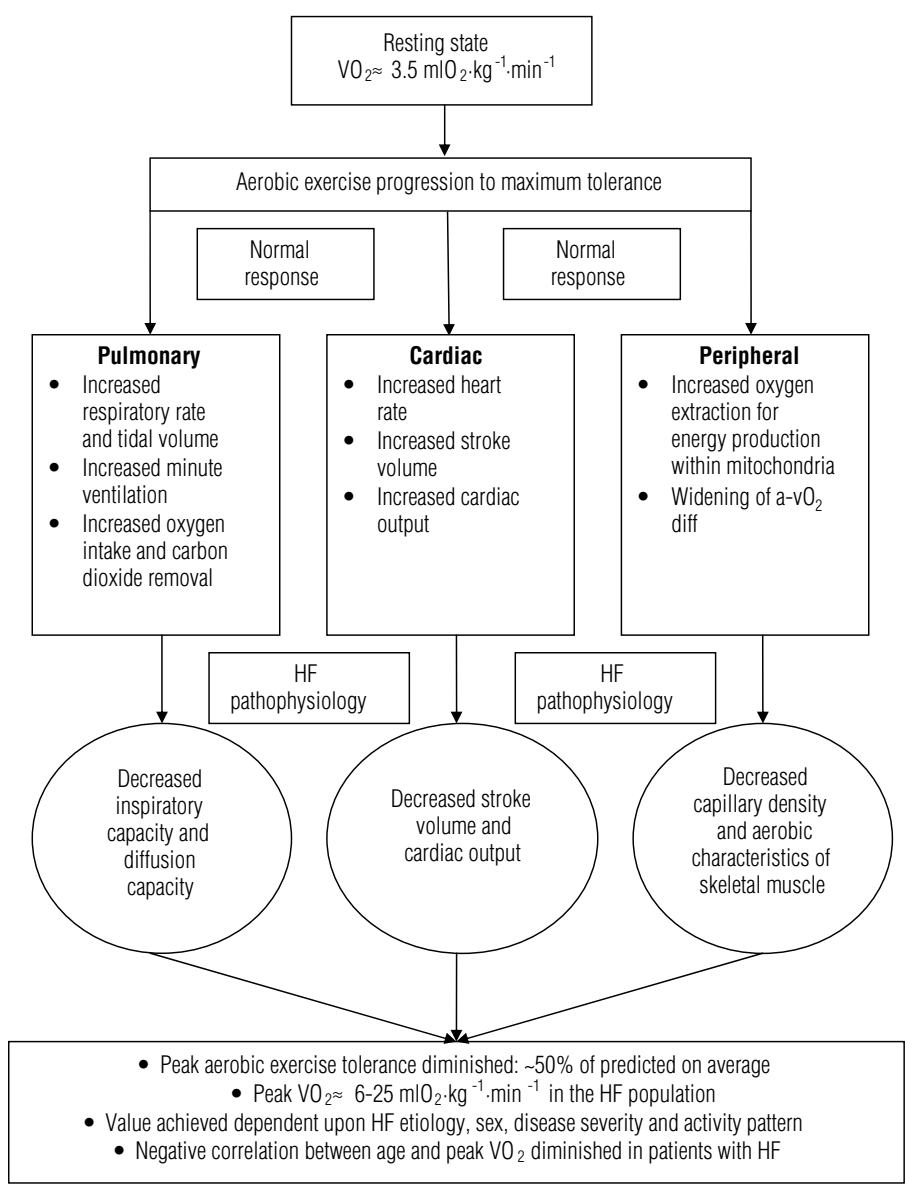

Figure 1. Illustration of central and peripheral physiological adaptations from rest to maximal aerobic exercise and the impact of heart failure.

Table 1. Key considerations for cardiopulmonary exercise testing variables in patients with heart failure.

\begin{tabular}{|c|c|c|c|}
\hline Variable & Prognostic value & Prognostic thresholds & Response to interventions \\
\hline VE/NCO ${ }_{2}$ Slope $^{*}$ & $\begin{array}{l}\text { Well established; } \\
>20 \text { papers } \\
\text { Single best prognostic marker }\end{array}$ & $\begin{array}{l}</ \geq 34 \text { as dichotomous threshold; prognosis } \\
\text { appears to progressively worsen as slope } \\
\text { increases into } 40 \text { s (VC-IV } \geq 45.0 \text { ) }\end{array}$ & $\begin{array}{l}\text { Significant reduction with multiple } \\
\text { interventions; should be assessed with } \\
\text { interventional trials }\end{array}$ \\
\hline Peak VO ${ }_{2}^{* \Sigma}$ & $\begin{array}{l}\text { Well established; } \\
>20 \text { papers }\end{array}$ & $\begin{array}{l}</ \geq 10 \mathrm{mlO}_{2} \cdot \mathrm{kg}^{-1} \cdot \mathrm{min}^{-1} \text { in patients prescribed } \\
\text { a beta-blocker; } \\
</ \geq 14 \mathrm{mlO}_{2} \cdot \mathrm{kg}^{-1} \cdot \mathrm{min}^{-1} \text { in patients not } \\
\text { prescribed a beta-blocker }\end{array}$ & $\begin{array}{l}\text { Significant reduction with multiple } \\
\text { interventions; should be assessed with } \\
\text { interventional trials }\end{array}$ \\
\hline $\mathrm{EOV}^{*}$ & $\begin{array}{l}\text { Consistent results; } \\
4 \text { papers }\end{array}$ & $\begin{array}{l}\text { Defined as oscillatory pattern in VE that } \\
\text { occurs for } \geq 60 \% \text { of the exercise test at an } \\
\text { amplitude } \geq 15 \% \\
\text { of average amplitude observed at rest }\end{array}$ & $\begin{array}{l}\text { Not well investigated; significant reduction } \\
\text { in occurrence of EOV following milrinone } \\
\text { treatment and respiratory muscle training }\end{array}$ \\
\hline OUES & $\begin{array}{l}\text { Compelling results; } \\
2 \text { papers }\end{array}$ & $\begin{array}{l}\text { Not well established at this time; } \\
\text { lower = worse prognosis }\end{array}$ & $\begin{array}{l}\text { Not well investigated; significantly improved } \\
\text { following exercise training }\end{array}$ \\
\hline $\begin{array}{l}\mathrm{P}_{\mathrm{ET}} \mathrm{CO}_{2} \\
\text { Rest and exercise }\end{array}$ & $\begin{array}{l}\text { Compelling results; } \\
2 \text { papers }\end{array}$ & $\begin{array}{l}\text { Not well established at this time; } \\
\text { lower = worse prognosis }\end{array}$ & $\begin{array}{l}\text { Response to interventions not investigated } \\
\text { at this time }\end{array}$ \\
\hline HRR & $\begin{array}{l}\text { Compelling results; } \\
3 \text { papers with small cohorts }\end{array}$ & $\begin{array}{l}\text { Not well established at this time; } \\
\text { lower = worse prognosis }\end{array}$ & $\begin{array}{l}\text { Not well investigated; significantly improved } \\
\text { following exercise training }\end{array}$ \\
\hline
\end{tabular}

Abbreviations: EOV= Exercise oscillatory ventilation; OUES= Oxygen uptake efficiency slope; $\mathrm{P}_{\mathrm{ET}} \mathrm{CO}_{2}=$ Partial pressure of end-tidal carbon dioxide; HRR= Heart rate recovery. * Combination of high $\mathrm{VE} / \mathrm{VCO}_{2}$ slope plus the presence of EOV and/or low peak $\mathrm{VO}_{2}$ may be highly indicative of poor prognosis; $\Sigma$ Use of peak $\mathrm{VO}_{2}$ for prognostic purposes not recommended if peak RER $<1.0$ and test terminated at subject's request; Similar peak RER values between/among exercise tests during interventional trials is indicative of consistent subject effort. 


\section{Peak oxygen consumption}

Oxygen consumption at peak exercise remains the most frequently assessed variable obtained from CPX in the HF population and is often significantly reduced, compared with normal predicted values for a given age. It is usually referred to as "peak $\mathrm{VO}_{2}$ " in patients with $\mathrm{HF}$, since a plateau in oxygen uptake is uncommon. Although ventilatory expired gas systems provide absolute peak $\mathrm{VO}_{2}$ data $(\mathrm{ml} / \mathrm{min}$ or $\mathrm{l} / \mathrm{min})$, it is most often reported clinically as a relative value $\left(\mathrm{mlO}_{2} \cdot \mathrm{kg}^{-1} \cdot \mathrm{min}^{-1}\right)$. Figure 2 illustrates a comparison of $\mathrm{VO}_{2}$ responses during symptom-limited CPX between an apparently healthy individual and a patient diagnosed with HF. Both subjects were 55-year-old males. A plateau in $\mathrm{VO}_{2}$ is observed in the apparently healthy individual $\left(\mathrm{VO}_{2 \max }\right)$ but is absent in the patient with $\mathrm{HF}$ (peak $\mathrm{VO}_{2}$ ). Values of 37.8 and $11.2 \mathrm{mlO}_{2} \cdot \mathrm{kg}^{-1} \cdot \mathrm{min}^{-1}$ place the apparently healthy individual and patient with $\mathrm{HF}$ in the $50^{\text {th }}$ and below the $10^{\text {th }}$ percentile for their age, respectively ${ }^{1}$.

Numerous investigations have reported relationships between peak $\mathrm{VO}_{2}$ and the pathophysiological abnormalities associated with HF. Lower cardiac output during exercise ${ }^{2-5}$, decreased alveolar-capillary membrane conductance ${ }^{28}$, decreased heart rate variability ${ }^{29}$, increased pulmonary vascular pressures $^{30,31}$ and increased brain natriuretic peptide ${ }^{32-34}$ have all been significantly correlated with lower peak $\mathrm{VO}_{2}$ in patients with HF. Furthermore, several interventions have been shown to significantly improve peak $\mathrm{VO}_{2}$, including aerobic exercise training ${ }^{35}$,inspiratory muscle training ${ }^{36}$, left ventricular assistance device implantation ${ }^{37}$, cardiac resynchronization therapy ${ }^{38}$, ACE inhibition ${ }^{39}$ and sildenafil ${ }^{40}$. Beta-blockade, however, has consistently been shown to have no effect on peak $\mathrm{VO}_{2} 41,42$.

Given the ability of peak $\mathrm{VO}_{2}$ to reflect varying degrees of disease severity, the consistently demonstrated prognostic value of this CPX variable should be of no surprise ${ }^{43-45}$. In fact, peak $\mathrm{VO}_{2}$ remains the most frequently analyzed variable in clinical practice with regard to prognostic assessment. A peak $\mathrm{VO}_{2}$ threshold of $</ \geq 14 \mathrm{mlO}_{2} \cdot \mathrm{kg}^{-1} \cdot \mathrm{min}^{-1}$ was established for prognostic purposes by Mancini et al. ${ }^{43}$ in 1991 and is still used today. More recently, O'Neil et al. ${ }^{46}$ found that this threshold might be too high in patients with HF who have been prescribed beta-blocking agents, a pharmacological class that improves survival but does not significantly improve peak $\mathrm{VO}_{2}$. Given these findings, a peak $\mathrm{VO}_{2}$ threshold of $</ \geq 10 \mathrm{mlO}_{2} \cdot \mathrm{kg}^{-1} \cdot \mathrm{min}^{-1}$ may be more appropriate for present-day practice, particularly given the large percentage of patients with HF who are prescribed beta-blockers.

Although peak $\mathrm{VO}_{2}$ is clearly an important prognostic variable, it does have limitations. The central limitation is dependence on maximal effort by the subject to attain a valid measurement. Mezzani et al.$^{47}$ demonstrated that the prognostic value of peak $\mathrm{VO}_{2} \leq 10 \mathrm{mlO}{ }_{2} \cdot \mathrm{kg}^{-1} \cdot \mathrm{min}^{-1}$ was significantly diminished in subjects who attained peak respiratory exchange ratio $($ RER) < 1.15 (clinical significance of peak RER is discussed in the following section). For this reason, the prognostic veracity of peak $\mathrm{VO}_{2}$ should be questioned among subjects who voluntarily terminate the exercise test and do demonstrate objective signs of maximal effort (i.e. high peak RER).

\section{Peak respiratory exchange ratio}

Achievement of at least $85 \%$ of age-predicted maximal heart rate is a classic indicator of maximal effort during the exercise test. The maximal heart rate response to exercise, however, has wide variability ( \pm 12 beats per minute) in the general population and this has a negative impact on the ability to use heart rate to accurately gauge subject effort. Furthermore, the use of beta-blocking agents, now commonplace in the HF population, dramatically and heterogeneously blunts the heart rate response at maximal

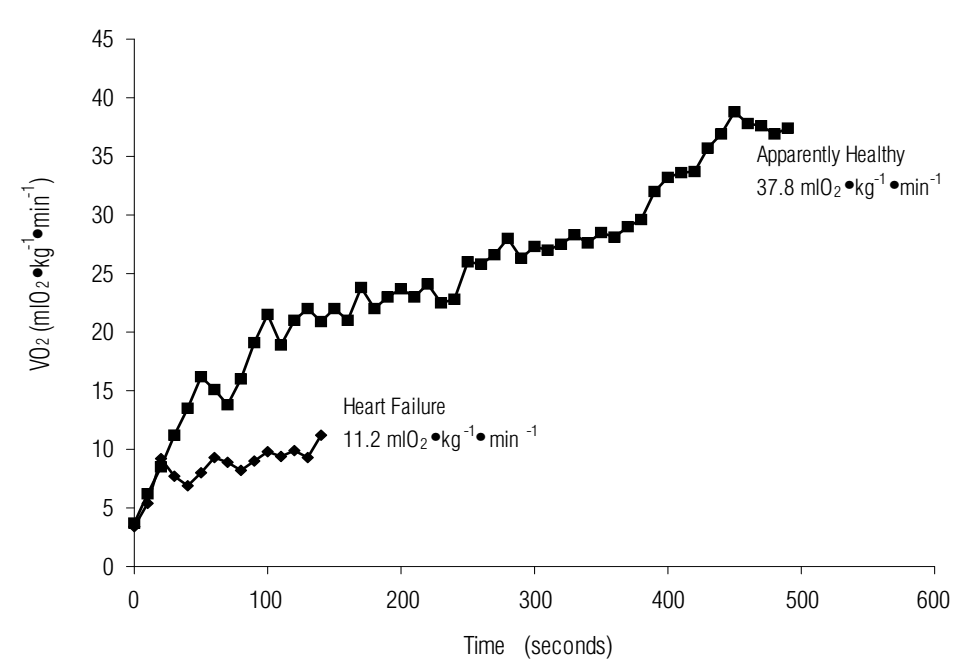

Figure 2. Oxygen consumption comparison during symptom-limited CPX: apparently healthy vs. heart failure. 
exercise, thus negating the validity of age-predicted maximal heart rate. The RER, defined as the ratio between $\mathrm{VCO}_{2}$ and $\mathrm{VO}_{2}$, is the most accurate way to assess subject effort during CPX. As exercise progresses to higher intensities, lactic acid buffering contributes towards $\mathrm{VCO}_{2}$, thereby increasing the numerator of this expression at a faster rate than the denominator. This physiological response to exercise is consistent across all individuals, making peak RER a reliable method for determining subject effort. Peak RER $\geq 1.10$ is an indication of excellent subject effort during CPX. As a minimal threshold, peak RER $<1.00$ during CPX that is terminated at the subject's request, with the absence of electrocardiographic and/or hemodynamic abnormalities (ST segment changes, ventricular arrhythmias, drop in systolic blood pressure, etc.), may be indicative of poor subject effort. Caution should therefore be applied in using peak $\mathrm{VO}_{2}$ for prognostic purposes when coinciding with a low peak RER. Assessment of peak RER is also important during interventional trials, to ensure comparable subject effort from one test to the next. A significant increase in aerobic capacity following a given intervention, with similar peak RER values, strongly supports the assertion that observed improvements are secondary to physiological adaptation.

\section{Oxygen consumption at ventilatory threshold}

Minute ventilation, $\mathrm{VO}_{2}$ and $\mathrm{VCO}_{2}$ all increase in a similar linear fashion during the initial stages of progressive exercise tests, because of increased aerobic metabolism. At a given submaximal level of exercise unique to each individual, anaerobic metabolism begins to increase. From this point to maximal exercise, there are two significant sources of $\mathrm{CO}_{2}$, consisting of byproducts from metabolism and lactic acid buffering. This causes a nonlinear rise in $\mathrm{VCO}_{2}$ in relation to $\mathrm{VO}_{2}^{48}$. Ventilation is driven by $\mathrm{VCO}_{2}$, thus causing a simultaneous nonlinear break in VE. The ability to detect this break point through ventilatory expired gas (ventilatory threshold) enables noninvasive estimation of the anaerobic threshold. The $\mathrm{VO}_{2}, \mathrm{VCO}_{2}$ and $\mathrm{VE}$ responses to progressive CPX are illustrated in Figure 3.

The v-slope, ventilatory equivalents and end-tidal $\mathrm{O}_{2} / \mathrm{CO}_{2}$ methods have all been used to determine the ventilatory threshold. Techniques for these calculations are described elsewhere ${ }^{49,50}$. Because of the significantly reduced aerobic capacity and/or oscillations in exercise ventilation among patients with HF, accurate determination of the ventilatory threshold is not always possible. When detectable, $\mathrm{VO}_{2}$ at ventilatory threshold, like peak $\mathrm{VO}_{2}$, is often significantly reduced in patients with HF. Although there is some evidence to indicate that $\mathrm{VO}_{2}$ at the ventilatory threshold is prognostically significant ${ }^{51}$, its analysis is at present more important as a core component of exercise prescription, with regard to the overload principle (discussed in a subsequent section).

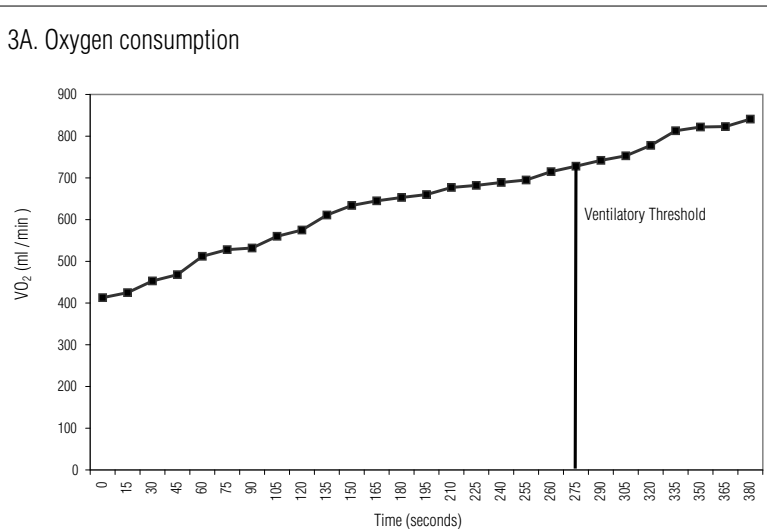

3B. Carbon dioxide production

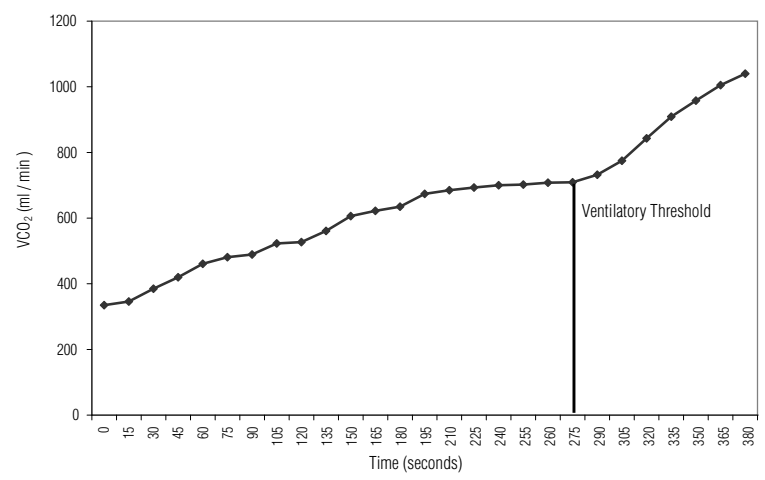

3C. Minute ventilation

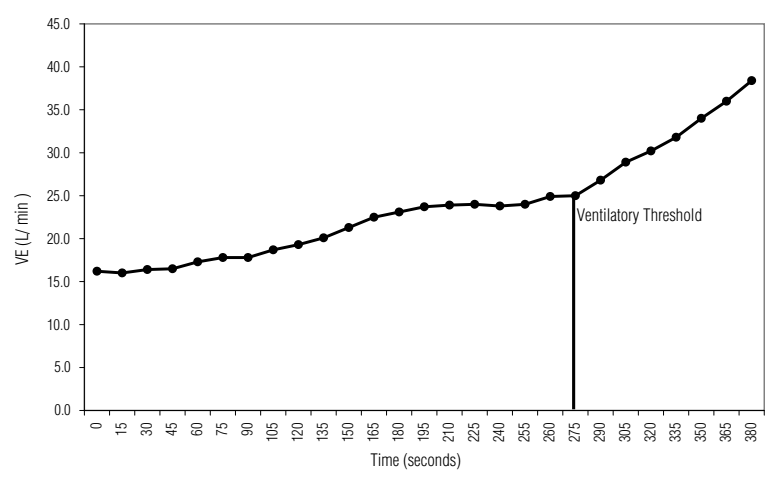

Figure 3. Detecting ventilatory threshold using oxygen consumption, carbon dioxide production and the minute ventilation response to exercise.

\section{The minute ventilation - carbon dioxide production relationship}

Minute ventilation and $\mathrm{VCO}_{2}$ are tightly coupled during exercise, since the former is driven by the metabolic and anaerobic production of the latter. The $\mathrm{VE}-\mathrm{VCO}_{2}$ relationship is most often expressed as a slope value, calculated by linear regression 


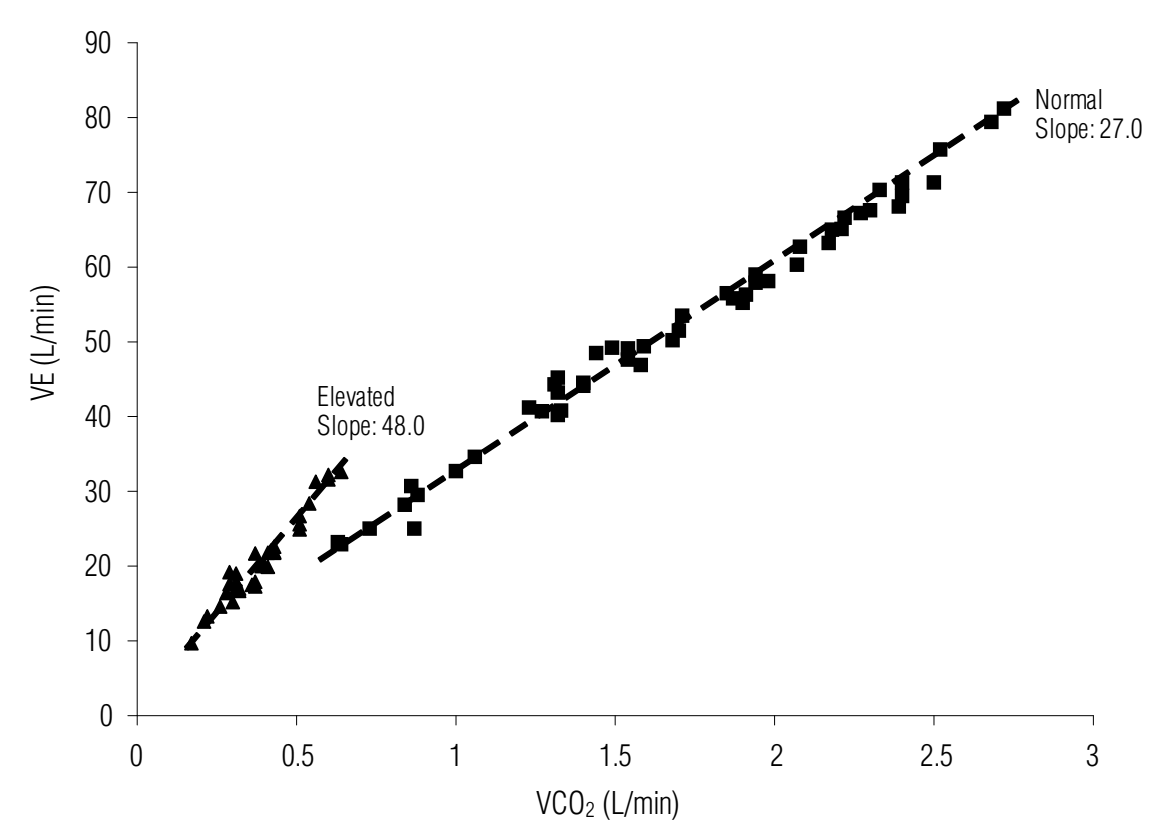

Figure 4. $\mathrm{VE} / \mathrm{NCO}_{2}$ slope comparison during symptom-limited $\mathrm{CPX}$ : normal vs. heart failure.

( $\mathrm{y}=\mathrm{mx}+\mathrm{b}, \mathrm{b}=$ slope). A VE/ $/ \mathrm{VCO}_{2}$ slope $<30$ is considered normal, while the range observed in $\mathrm{HF}$ is $<30$ to $>70$. Figure 4 illustrates normal and elevated $\mathrm{VE} / \mathrm{VCO}_{2}$ slope responses to progressive exercise tests on two patients diagnosed with HF.

The pathophysiological mechanism behind an abnormally elevated $\mathrm{VE} / \mathrm{VCO}_{2}$ slope in $\mathrm{HF}$ patients appears to be multifactorial. Centrally, an elevated $\mathrm{VE} / \mathrm{VCO}_{2}$ slope has been linked to ventilation-perfusion abnormalities (adequate ventilation and poor perfusion $)^{52,53}$. Additionally, elevated $\mathrm{VE} / \mathrm{VCO}_{2}$ slopes have demonstrated significant correlations with abnormally increased chemo and ergoreceptor sensitivity ${ }^{54-56}$, both contributing towards exaggerated ventilatory response to exercise. Like peak $\mathrm{VO}_{2}$, the $\mathrm{VE} / \mathrm{VCO}_{2}$ slope has been significantly correlated with decreased cardiac output ${ }^{30,31,57}$, increased pulmonary pressures ${ }^{30}$, decreased alveolar-capillary membrane conductance ${ }^{58}$ and decreased heart rate variability ${ }^{32,33}$. Also consistent with peak $\mathrm{VO}_{2}$, several interventions have been shown to significantly improve the $\mathrm{VE}-\mathrm{VCO}_{2}$ relationship, including aerobic exercise training ${ }^{35}$, inspiratory muscle training ${ }^{36}$, left ventricular assistance device implantation ${ }^{37}$, cardiac resynchronization therapy ${ }^{38}$, ACE inhibition ${ }^{39}$ and Sildena$\mathrm{fil}^{40}$. In contrast to peak $\mathrm{VO}_{2}$, beta-blockade has also been shown to significantly improve the $\mathrm{VE}-\mathrm{VCO}_{2}$ relationship ${ }^{41,42}$.

Given the link between the $\mathrm{VE}-\mathrm{VCO}_{2}$ relationship and pathophysiology, considerable attention has been given to the prognostic value of this CPX variable. The $\mathrm{VE}-\mathrm{VCO}_{2}$ relationship, again most often expressed as a slope, has consistently been shown to have high prognostic value in patients with $\mathrm{HF}^{21,45,59-61}$. For prognostic purposes, the most frequently used dichotomous $\mathrm{VE} / \mathrm{VCO}_{2}$ slope threshold is $</ \geq 34^{49,62}$. A four-level ventilatory classification (VC) scheme based upon the VE/ $\mathrm{VCO}_{2}$ slope (VC-I: < 29.9, VC-II: 30.0-35.9, VC-III: 36.04.9, VC-IV: $\geq 45.0$ ) may, however, better identify varying levels of risk of adverse events ${ }^{21}$. Irrespective of the $\mathrm{VE} / \mathrm{VCO}_{2}$ slope threshold that is used, this variable should be calculated using all the exercise data (beginning of exercise to peak exertion), as opposed to submaximal calculations. Using all the exercise data to calculate the $\mathrm{VE} / \mathrm{VCO}_{2}$ slope has consistently been shown to provide stronger prognostic information ${ }^{61,63}$. Furthermore, the $\mathrm{VE}^{-\mathrm{VCO}_{2}}$ relationship appears to be prognostically superior to peak $\mathrm{VO}_{2}{ }^{62}$. One of the primary reasons for the consistent prognostic superiority of the $\mathrm{VE}-\mathrm{VCO}_{2}$ relationship over peak $\mathrm{VO}_{2}$ is its independence from subject effort. Furthermore, diagnostic studies have shown that, while both the $\mathrm{VE}-\mathrm{VCO}_{2}$ relationship and peak $\mathrm{VO}_{2}$ are correlated with the same pathophysiological markers (reduced cardiac output, elevated neurohormonal markers, etc), the relationship with the former CPX variable and these pathophysiological markers is stronger ${ }^{62}$. The body of evidence in this area supports the use of the $\mathrm{VE} / \mathrm{VCO}_{2}$ slope as the primary variable assessed when CPX is performed for prognostic purposes in HF populations. It should be noted that, while the $\mathrm{VE} / \mathrm{VCO}_{2}$ slope has consistently been the strongest prognostic marker in previous investigations, peak $\mathrm{VO}_{2}$ was retained in multivariate regression analyses in approximately half of the studies comparing these CPX variables ${ }^{62}$. For this 

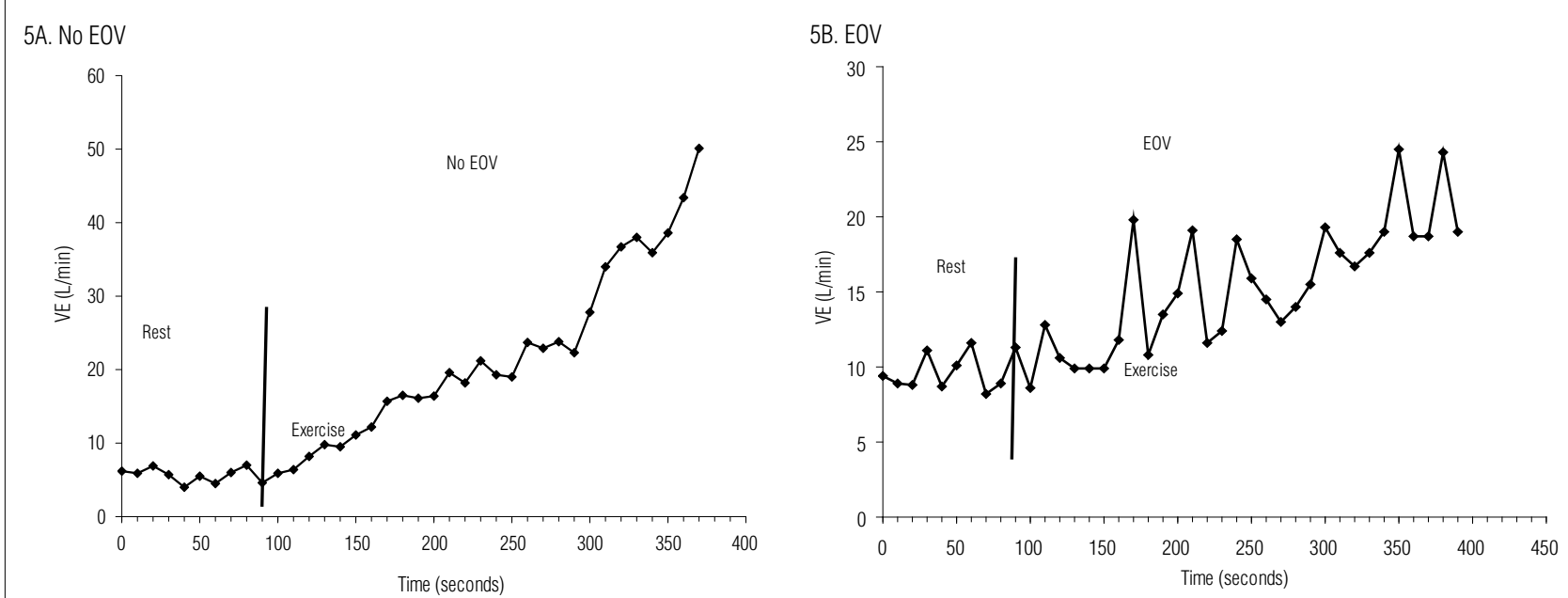

Figure 5. Example of exercise ventilatory patterns in two subjects with heart failure.

reason, we recommend the analysis of both the $\mathrm{VE} / \mathrm{VCO}_{2}$ slope and peak $\mathrm{VO}_{2}$ in clinical practice.

\section{Exercise oscillatory ventilation}

Minute ventilation generally increases linearly during progressive exercise tests. In HF populations, however, a number of patients present a waxing/waning VE pattern than has been defined as exercise oscillatory ventilation (EOV). The body of research investigating this phenomenon in patients with $\mathrm{HF}$ is not as robust as the work done in the areas of peak $\mathrm{VO}_{2}$ and the VE- $-\mathrm{VCO}_{2}$ relationship. The analysis of EOV in HF does, however, rather convincingly indicate that disease severity is significantly increased when this ventilatory abnormality is present ${ }^{64,65}$. Although there is at present no universal definition of EOV, an oscillatory VE pattern at rest that persists for $\geq 60 \%$ of the exercise test at an amplitude $\geq 15 \%$ of the average resting value has been proposed ${ }^{66,67}$. Figure 5 illustrates the VE pattern at rest and during a progressive exercise test in two patients diagnosed with HF: one with a normal pattern and the other with EOV.

Like elevated $\mathrm{VE} / \mathrm{VCO}_{2}$ slopes, EOV has been linked to increased chemosensitivity in patients with $\mathrm{HF}^{68}$. In addition, oscillations in cardiac function have been reported in patients with $\mathrm{EOV}^{69}$. Using quantitative algebraic analysis of dynamic cardiorespiratory physiology, Francis et al. ${ }^{70}$ concluded that the primary pathophysiological factors resulting in EOV are circulatory delay and an increased chemoreflex gain. While the impact of interventions on EOV are limited, both milrinone ${ }^{64}$ and respiratory muscle training ${ }^{36}$ have been shown to reduce the occurrence of EOV.

Like peak $\mathrm{VO}_{2}$ and the $\mathrm{VE} / \mathrm{VCO}_{2}$ slope, the presence of $\mathrm{EOV}$ appears to be a significant predictor of adverse events $\mathbf{s}^{66,67,71,72}$.
Furthermore, combined assessment of EOV and both peak $\mathrm{VO}_{2}{ }^{67}$ and the $\mathrm{VE} / \mathrm{VCO}_{2}$ slope ${ }^{72}$ appears to enhance prognostic significance, thus warranting their inclusion when using CPX data to assess prognosis. The combination of the independence of EOV from subject effort and its ability to reflect cardiac pathophysiology may help to account for the strong prognostic value observed in previous investigations.

\section{Other noteworthy cardiopulmonary exercise testing variables}

Several other CPX variables have been assessed for their prognostic value in patients with HF. The oxygen uptake efficiency slope (OUES), defined as the linear relationship between $\mathrm{VO}_{2}$ and the logarithmic transformation of $\mathrm{VE}^{73,74}$, the partial pressure of end-tidal carbon-dioxide production at rest ${ }^{75}$ and during exercise $e^{76}$, and heart rate recovery $(\mathrm{HRR})^{77-79}$ have all demonstrated prognostic value among patients with HF. Furthermore, both the OUES ${ }^{80}$ and $\mathrm{HRR}^{81}$ have been shown to significantly increase (improve) following an aerobic exercise training program among patients with HF. The additive prognostic value of these variables to peak $\mathrm{VO}_{2}$, the $\mathrm{VE} / \mathrm{VCO}_{2}$ slope and $\mathrm{EOV}$ is unclear at this time. Future investigations are needed in order to determine whether one or more of the variables mentioned should be added to multivariate modeling. Lastly, although not central to the prognostic assessment of patients with HF, monitoring of the hemodynamic and electrocardiographic response to CPX should be performed, particularly to identify potentially life-threatening situations that warrant test termination. A fall in systolic blood pressure during exercise compared with baseline measurements is a test termination criterion ${ }^{20,26}$ that potentially reflects worsening left ventricular performance 
and may be a particularly ominous prognostic marker ${ }^{82-85}$. Likewise, electrocardiographic evidence of ischemia and/or ventricular arrhythmia is a potentially serious indicator of worsening cardiac function during exercise and may also warrant termination of the $\mathrm{CPX}^{26}$.

\section{Aerobic exercise training considerations in patients with heart failure $: \because$.}

\section{General principles of aerobic exercise training}

The overload, specificity and reversibility principles are key considerations in developing an effective aerobic exercise program. The overload principle relates to the fact that the training stimulus must be greater than what the physiological systems (i.e. cardiovascular and skeletal muscle) are accustomed to, for a positive adaptation to occur. The mode, intensity, duration and frequency of aerobic exercise are considered in combination, in order to safely use the overload principle for a given training program. Among patients with $\mathrm{HF}$, overload can typically be achieved at a lower training level, particularly during the initial phases of the exercise program, compared with apparently healthy subjects. The specificity principle states that physiological improvements are unique to the mode of exercise performed. For example, walking performance will be optimized with a training program primarily focusing on treadmill training as opposed to lower-limb ergometry or swimming. However, the positive health-related adaptations observed in patients with HF who participate in aerobic exercise training (discussed in a subsequent section) are achieved with any type of exercise using large muscle groups on a continuous basis (walking/running, lower-limb ergometry, elliptical devices, etc). For the overwhelming majority of patients with HF, the specificity principle is less important than the fact that moderate aerobic activity of any type has numerous health benefits. The type of exercise should therefore be driven by individual preference and the availability of necessary equipment. Lastly, the reversibility principle states that positive training adaptations are not maintained if an individual returns to a sedentary behavior pattern. Life-long participation in the prescribed aerobic exercise program should therefore be a primary goal.

\section{Specific recommendations} for aerobic exercise prescription

Once contraindicated, aerobic exercise training is now a well-accepted lifestyle intervention for patients with compensated HF. The general frequency, duration and intensity recommendations for aerobic exercise in this population are 3-5 days/weeks, 30-60 minutes and 50-80\% of maximal aerobic capacity, respectively ${ }^{7,14}$. Walking (treadmill, track or other measured course), lower-limb cycle ergometry (mobile or stationary) or elliptical units enable physical stressing of larger muscle groups and are therefore acceptable types of exercise. Patients with HF should be guided to progress in frequency, duration and intensity towards the upper end of these aerobic exercise recommendations (i.e. 5 days per week, $\sim 60$ minutes per session, $70-80 \%$ of maximal aerobic capacity) over several weeks/ months. While all patients should strive to ultimately achieve these recommendations, it should be recognized that some level of physical activity is always preferable to a sedentary lifestyle.

While continuous aerobic exercise is the ultimate goal, some debilitated patients with HF will not be able to sustain an exercise session for the entire time period at a given intensity, particularly during the initial stages of the training program. In these instances, interval training, i.e. periods consisting of 1-2 minutes of exercise at the desired intensity followed by a lower intensity recovery period, should be used. Progression for patients performing interval training entails a gradual increase in the training duration at a given exercise intensity (1-2 to 2-4 to 4-6 minutes, etc.) before it becomes necessary to start the lower intensity recovery period. The goal is to guide these patients to progress to continuous bouts of aerobic activity (i.e. 30-60 minutes) over several weeks/months of training.

Titration of exercise intensity is the exercise prescription component most frequently used to optimize the overload principle. Irrespective of the method used to set exercise intensity, it should be established by an exercise test, preferably in conjunction with ventilatory expired gas analysis, performed at the start of the training program. Because peak $\mathrm{VO}_{2}$ is significantly improved as a result of certain pharmacologic interventions ${ }^{39,40}$ and cardiac resynchronization therapy ${ }^{38}$, the ideal is to perform the baseline exercise test after these treatment options have been implemented. Identification of the ventilatory threshold via CPX is the preferred method for setting exercise intensity, since it enables identification of a specific heart rate and workload at which anaerobic metabolism begins to increase during exercise. Setting the training intensity at the heart rate or workload corresponding to the ventilatory threshold ensures the overload principle is correctly used, since the typical patient with HF is not accustomed to exercising at levels that correspond to an initial increase in anaerobic metabolism. When the ventilatory threshold is undetectable, prescribing an exercise intensity of between $50 \%$ and $80 \%$ of peak $\mathrm{VO}_{2}$ is appropriate. If the peak $\mathrm{VO}_{2}$ range method is used to prescribe exercise intensity, it is recommended that HF patients begin the training program at the 
lower end of this range (50\%) and gradually progress to $80 \%$ of the baseline peak $\mathrm{VO}_{2}$ over several weeks or months of aerobic exercise training. The heart rate associated with this peak $\mathrm{VO}_{2}$ range can be used to monitor compliance with the prescribed exercise intensity during individual training sessions. Because of the potential day-to-day variability associated with heart failure medical management and/or stability, setting an individual exercise session at $\pm 5 \%$ of the specific target intensity is recommended ${ }^{14}$. For example, for a patient with a target exercise heart rate of 120 beats per minute, $a \pm 5 \%$ range would be 114-126 beats per minute. Alternatively, a perceived exertion level of 12-14 (on the Borg scale from 6 to 20) may be used to set the exercise intensity for patients who rate their exertion appropriately during the baseline exercise test.

The level of supervision, particularly at the initial stages of the exercise program, is an important consideration for this high-risk patient population. It is no longer considered necessary to recommend that all patients with HF undergo supervised exercise training with continuous electrocardiographic monitoring. This advanced level of supervision should, however, be strongly considered for patients with a history of cardiac arrhythmias, documented coronary artery disease that has not been surgically addressed or a low ejection fraction $(\leq 25 \%)$, or whose characteristics resemble those of patients who suffered sudden cardiac death ${ }^{14}$. Furthermore, irrespective of past medical history, patients who demonstrate an abnormal hemodynamic (hypertensive/hypotensive) response and/or electrocardiographic (ischemia/ventricular arrhythmias) abnormalities during the baseline exercise test should undergo supervised exercise training for some period of time. The duration and number of supervised exercise sessions is at the discretion of the health professional responsible for the training program. As a general guideline, patients should demonstrate an ability to appropriately self-monitor the exercise session and not have any abnormal physiological responses for several weeks before progressing to unmonitored exercise.

\section{Documented benefits of aerobic exercise training}

There is now a rather impressive body of research demonstrating numerous health-related benefits associated with aerobic exercise training among patients with $\mathrm{HF}^{7,35,62,81,86,87}$. The benefits that have been documented are listed in Table 2. Furthermore, the adverse event rate with exercise training appears to be low?

While one large trial examining the impact of aerobic exercise training on survival and hospitalization among patients with $\mathrm{HF}$ is ongoing ${ }^{88}$, no findings have been published to date. A meta-analysis on this topic, pooling together a number of smaller exercise trials (combined $n=801$ ), demonstrated a significant increase in survival and significant reduction in hospitalization in the exercise training group, compared with controls. These results need to be confirmed by future prospective investigations. Lastly, the work cited in this section was exclusively performed on patients diagnosed with systolic HF. The initial evidence indicates that the improvements in peak $\mathrm{VO}_{2}$ and quality of life following exercise training are similar in patients with systolic and diastolic $\mathrm{HF}^{89}$. Despite these initial findings, caution should be applied in extrapolating the documented benefits of exercising training listed in Table 2 to the diastolic HF population.

\section{Complementary interventions also shown to improve aerobic capacity}

Several other interventions within allied health professionals' scope of practice have been shown to improve peak $\mathrm{VO}_{2}$ and should be considered as potential complements to the aerobic exercise training program on an individual basis. Unlike in apparently healthy populations, resistance training programs have been shown to significantly improve peak $\mathrm{VO}_{2}$ among patients with $\mathrm{HF}^{90}$. In addition, resistance training improves bone mineral density, muscle mass and muscle force production to a greater extent than aerobic exercise programs do. In general, resistance training programs for patients with HF should focus on higher numbers of repetitions ( $\approx 1-3$ sets of $10-12$ repetitions) at a lower load ( $\approx 50 \%$ of one-repetition maximum). Additional general recommendations include a training frequency of 1-3 days per week, targeting large muscle groups with 4-9 training stations. Cable or hydraulic resistance systems may be preferable to free weights, from a patient-safety perspective. Subjects with a greater level of HF severity (New York Heart Class I-II vs. Class II-III) should be set tasks at the lower range of these recommendations ${ }^{90}$. As previously mentioned, subjects with HF may present varying levels of inspiratory capacity impairment that seems to be correlated with peak $\mathrm{VO}_{2}{ }^{15,16}$. Inspiratory muscle training may improve respiratory muscle function and peak $\mathrm{VO}_{2}^{36}$. This treatment alternative should

Table 2. Benefits of aerobic exercise training in patients with heart failure.

\begin{tabular}{ll}
\hline - & Improvement in quality of life \\
\hline - & Increase in peak $\mathrm{VO}_{2}$ \\
\hline - & Increase in $\mathrm{VO}_{2}$ at ventilatory threshold \\
\hline - & Reduction in the $\mathrm{VE} / \mathrm{VCO}_{2}$ slope \\
\hline - & Increase in heart rate recovery \\
\hline - & Improvement in endothelial function \\
\hline - & Improvement in aerobic characteristics of skeletal muscle \\
\hline - & Improvement in autonomic tone \\
\hline$\bullet$ & Improvement in resting indices of cardiac function \\
\hline- & Improvement in cardiac output at maximal exercise \\
\hline
\end{tabular}


be considered when an HF patient presents an inspiratory capacity that is below the normative values predicted for the age and sex. Lastly, chronic electrical myostimulation has been shown to significantly improve muscle force production ${ }^{91}, \mathrm{VO}_{2}$ at ventilatory threshold ${ }^{92}$ and peak $\mathrm{VO}_{2}{ }^{92,93}$ in patients with HF. These programs typically consist of myostimulation to lower extremity muscle groups (bilateral quadriceps plus hamstring or calf muscles), for one to several hours most days of the week for several weeks. Implementation of a myostimulation program may be particularly advantageous for severely debilitated patients who initially are unable to perform continuous aerobic exercise sessions.

\section{Summary $:: \therefore$}

There is now a robust body of evidence demonstrating the clinical value of both CPX and aerobic exercise training for systolic HF populations. Cardiopulmonary exercise testing provides valuable prognostic information, is valuable in assessing the response to numerous interventions and is important in developing individualized exercise prescriptions. Participation in an aerobic exercise program is a safe means for improving functional capacity, quality of life and numerous physiological measurements. There is also promising evidence to indicate that aerobic exercise training improves morbidity and mortality in systolic HF populations. These findings need to be reproduced in patients with diastolic HF before concrete CPX and aerobic exercise training recommendations are made for this subgroup. Allied health professionals who are responsible for assessing and treating patients with HF should be aware of the importance of CPX, aerobic exercise training and complementary interventions and, when appropriate, advocate their implementation.

\section{References}

1. Armstrong L, Balady G, Berry M et al. Health-Related Physical Testing and Interpretation. In: Whaley MH, Brubaker PH, Otto R, editors. ACSM's Guidelines for exercise testing and prescription. 7th ed. Philadelphia: Lippincott Williams and Wilkins; 2007. p. 55-92.

2. Tanabe Y, Nakagawa I, Ito E, Suzuki K. Hemodynamic basis of the reduced oxygen uptake relative to work rate during incremental exercise in patients with chronic heart failure. Int J of Cardiol. 2002;83:57-62.

3. Matsumoto A, Itoh $\mathrm{H}$, Eto $\mathrm{Y}$, Kobayashi T, Kato M, Omata M, et al. End-tidal CO2 pressure decreases during exercise in cardiac patients: association with severity of heart failure and cardiac output reserve. J Am Coll Cardiol. 2000;36:242-9.

4. Metra M, Faggiano P, D'Aloia A, Nodari S, Gualeni A, Raccagni D, et al. Use of cardiopulmonary exercise testing with hemodynamic monitoring in the prognostic assessment of ambulatory patients with chronic heart failure. $\mathrm{J}$ Am Coll Cardiol. 1999;33:943-50.

5. Myers J, Gujja P, Neelagaru S, Burkhoff D. Cardiac output and cardiopulmonary responses to exercise in heart failure: Application of a new bio-reactance device. J Card Fail. 2007;13:629-36.

6. Duscha BD, Kraus WE, Keteyian SJ, Sullivan MJ, Green HJ, Schachat $\mathrm{FH}$, et al. Capillary density of skeletal muscle: a contributing mechanism for exercise intolerance in class II-III chronic heart failure independent of other peripheral alterations. J Am Coll Cardiol. 1999;33:1956-63

7. Pina IL, Apstein CS, Balady GJ, Belardinelli R, Chaitman BR, Duscha $\mathrm{BD}$, et al. Exercise and heart failure: $\mathrm{A}$ statement from the american heart association committee on exercise, Rehabilitation, and Prevention. Circulation. 2003;107:1210-25.
8. Hambrecht R, Fiehn E, Yu J, Niebauer J, Weigl C, Hilbrich L, et al. Effects of endurance training on mitochondrial ultrastructure and fiber type distribution in skeletal muscle of patients with stable chronic heart failure. J Am Coll Cardiol. 1997;29:1067-73.

9. Bekedam MA, van Beek-Harmsen BJ, Boonstra A, van MW, Visser FC, van der Laarse WJ. Maximum rate of oxygen consumption related to succinate dehydrogenase activity in skeletal muscle fibres of chronic heart failure patients and controls. Clin Physiol Funct Imaging. 2003; 23:337-43.

10. Witte KK, Clark AL. Why does chronic heart failure cause breathlessness and fatigue? Prog Cardiovasc Dis. 2007;49:366-84.

11. Mettauer B, Zoll J, Garnier A, Ventura-Clapier R. Heart failure: a model of cardiac and skeletal muscle energetic failure. Pflugers Archiv. 2006;452:653-66.

12. Sullivan MJ, Knight JD, Higginbotham MB, Cobb FR. Relation between central and peripheral hemodynamics during exercise in patients with chronic heart failure. Muscle blood flow is reduced with maintenance of arterial perfusion pressure. Circulation. 1989;80:769-81.

13. Myers J, Froelicher VF. Hemodynamic determinants of exercise capacity in chronic heart failure. Ann Intern Med. 1991;115:377-86.

14. Myers J. Principles of exercise prescription for patients with chronic heart failure. Heart Fail Rev. 2008;13:61-8.

15. Nanas S, Nanas J, Papazachou O, Kassiotis C, Papamichalopoulos A, Milic-Emili J, et al. Resting lung function and hemodynamic parameters as predictors of exercise capacity in patients with chronic heart failure. Chest. 2003;123:1386-93 
16. Papazachou O, Anastasiou-Nana M, Sakellariou D, Tassiou A, Dimopoulos $\mathrm{S}$, Venetsanakos $\mathrm{J}$, et al. Pulmonary function at peak exercise in patients with chronic heart failure. Int J Cardiol. 2007;118:28-35.

17. Agostoni P, Bussotti M, Cattadori G, Margutti E, Contini M, Muratori M, et al. Gas diffusion and alveolar-capillary unit in chronic heart failure. Eur Heart J. 2006;27:2538-43.

18. Meyer K, Westbrook S, Schwaibold M, Hajic R, Peters K, Roskamm H. Short-term reproducibility of cardiopulmonary measurements during exercise testing in patients with severe chronic heart failure. Am Heart J. 1997:134:20-6.

19. Gibbons RJ, Balady GJ, Beasley JW, Bricker JT, Duvernoy WF, Froelicher VF, et al. ACC/AHA Guidelines for exercise testing. A report of the American College of Cardiology/American Heart Association Task Force on Practice Guidelines (Committee on Exercise Testing). J Am Coll Cardiol. 1997; 30:260-311.

20. Gibbons RJ, Balady GJ, Timothy BJ, Chaitman BR, Fletcher GF, Froelicher VF, et al. ACC/AHA 2002 guideline update for exercise testing: summary article. A report of the American College of Cardiology/American Heart Association Task Force on Practice Guidelines (Committee to Update the 1997 Exercise Testing Guidelines). J Am Coll Cardiol. 2002; 40:1531-40.

21. Arena R, Myers J, Abella J, Peberdy MA, Bensimhon D, Chase P, et al. Development of a ventilatory classification system in patients with heart failure. Circulation. 2007;115:2410-7.

22. Piepoli MF, Corra U, Agostoni PG, Belardinelli R, Cohen-Solal A, Hambrecht $\mathrm{R}$, et al. Statement on cardiopulmonary exercise testing in chronic heart failure due to left ventricular dysfunction: recommendations for performance and interpretation. Part I: definition of cardiopulmonary exercise testing parameters for appropriate use in chronic heart failure. Eur J Cardiovasc Prev Rehabil. 2006;13:150-64.

23. Piepoli MF, Corra U, Agostoni PG, Belardinelli R, Cohen-Solal A, Hambrecht $\mathrm{R}$, et al. Statement on cardiopulmonary exercise testing in chronic heart failure due to left ventricular dysfunction: recommendations for performance and interpretation Part II: How to perform cardiopulmonary exercise testing in chronic heart failure. Eur J Cardiovasc Prev Rehabil. 2006;13:300-11.

24. Piepoli MF, Corra U, Agostoni PG, Belardinelli R, Cohen-Solal A, Hambrecht $\mathrm{R}$, et al. Statement on cardiopulmonary exercise testing in chronic heart failure due to left ventricular dysfunction: recommendations for performance and interpretation Part III: Interpretation of cardiopulmonary exercise testing in chronic heart failure and future applications. Eur J Cardiovasc Prev Rehabil. 2006;13:485-94.

25. Arena R, Humphrey R, Peberdy MA, Madigan M. Predicting peak oxygen consumption during a conservative ramping protocol: implications for the heart failure population. J Cardiopulm Rehabil. 2003; 23:183-9.

26. Fletcher GF, Balady GJ, Amsterdam EA, Chaitman B, Eckel R, Fleg J, et al. Exercise standards for testing and training: a statement for healthcare professionals from the American Heart Association. Circulation. 2001;104:1694-740.

27. Guazzi M, Myers J, Arena R. Cardiopulmonary exercise testing in the clinical and prognostic assessment of diastolic heart failure. J Am Coll Cardiol. 2005;46:1883-90.
28. Guazzi M, Pontone G, Brambilla R, Agostoni P, Reina G. Alveolar-capillary membrane gas conductance: a novel prognostic indicator in chronic heart failure. Eur Heart J. 2002;23:467-76.

29. Ponikowski P, Chua TP, Piepoli M, Banasiak W, Anker SD, Szelemej R, et al. Ventilatory response to exercise correlates with impaired heart rate variability in patients with chronic congestive heart failure. Am J Cardiol. 1998;82:338-44.

30. Reindl I, Wernecke KD, Opitz C, Wensel R, Konig D, Dengler T, et al. Impaired ventilatory efficiency in chronic heart failure: possible role of pulmonary vasoconstriction. Am Heart J. 1998;136:778-85.

31. Myers J, Dziekan G, Goebbels U, Dubach P. Influence of high-intensity exercise training on the ventilatory response to exercise in patients with reduced ventricular function. Med Sci Sports Exerc.1999; 31:929-37.

32. Kruger S, Graf Ju, Kunz D, Stickel T, Hanrath P, Janssens U. brain natriuretic peptide levels predict functional capacity in patients with chronic heart failure. J Am Coll Cardiol. 2002;40:718-22

33. Passino C, Poletti R, Bramanti F, Prontera C, Clerico A, Emdin M. Neurohormonal activation predicts ventilatory response to exercise and functional capacity in patients with heart failure. Eur J Heart Fail. 2006;8:46-53.

34. Scardovi AB, De MR, Coletta C, Aspromonte N, Perna S, Infusino T, et al. Brain natriuretic peptide is a reliable indicator of ventilatory abnormalities during cardiopulmonary exercise test in heart failure patients. Med Sci Monit. 2006;12:CR191-5.

35. Guazzi M, Reina G, Tumminello G, Guazzi MD. Improvement of alveolarcapillary membrane diffusing capacity with exercise training in chronic heart failure. J Appl Physiol. 2004;97:1866-73.

36. Dall'Ago P, Chiappa GR, Guths H, Stein R, Ribeiro JP. Inspiratory muscle training in patients with heart failure and inspiratory muscle weakness: a randomized trial. J Am Coll Cardiol. 2006;47:757-63.

37. de Jonge N, Kirkels H, Lahpor JR, Klopping C, Hulzebos EJ, de la Riviere $A B$, et al. Exercise performance in patients with end-stage heart failure after implantation of a left ventricular assist device and after heart transplantation: an outlook for permanent assisting? J Am Coll Cardiol. 2001;37:1794-9.

38. Auricchio A, Stellbrink C, Sack S, Block M, Vogt Ju, Bakker P, et al. Longterm clinical effect of hemodynamically optimized cardiac resynchronization therapy in patients with heart failure and ventricular conduction delay. J Am Coll Cardiol. 2002;39:2026-33.

39. Guazzi M, Marenzi G, Alimento M, Contini M, Agostoni P. Improvement of alveolar-capillary membrane diffusing capacity with enalapril in chronic heart failure and counteracting effect of aspirin. Circulation. 1997; 95:1930-6.

40. Guazzi M, Samaja M, Arena R, Vicenzi M, Guazzi MD. Long-term use of Sildenafil in the therapeutic management of heart failure. J Am Coll Cardiol. 2007:50:2136-44.

41. Agostoni P, Guazzi M, Bussotti M, De Vita S, Palermo P. Carvedilol reduces the inappropriate increase of ventilation during exercise in heart failure patients. Chest. 2002;122:2062-7.

42. Wolk R, Johnson BD, Somers VK, Allison TG, Squires RW, Gau GT, et al. Effects of [beta]-Blocker therapy on ventilatory responses to exercise in patients with heart failure. J Card Fail. 2005;11:333-9. 
43. Mancini DM, Eisen H, Kussmaul W, Mull R, Edmunds LH Jr., Wilson JR. Value of peak exercise oxygen consumption for optimal timing of cardiac transplantation in ambulatory patients with heart failure. Circulation. 1991;83:778-86.

44. Myers J, Gullestad L, Vagelos R, Do D, Bellin D, Ross H, et al. Cardiopulmonary exercise testing and prognosis in severe heart failure: 14 $\mathrm{mL} / \mathrm{kg} / \mathrm{min}$ revisited. Am Heart J. 2000;139:78-84.

45. Arena R, Myers J, Aslam SS, Varughese EB, Peberdy MA. Peak V02 and VE/VCO2 slope in patients with heart failure: a prognostic comparison. Am Heart J. 2004;147:354-60.

46. O'Neill JO, Young JB, Pothier CE, Lauer MS. Peak oxygen consumption as a predictor of death in patients with heart failure receiving \{beta\}-blockers. Circulation. 2005;111:2313-8

47. Mezzani A, Corra U, Bosimini E, Giordano A, Giannuzzi P. Contribution of peak respiratory exchange ratio to peak V02 prognostic reliability in patients with chronic heart failure and severely reduced exercise capacity. Am Heart J. 2003;145:1102-7.

48. Wilson JR, Ferraro N, Weber KT. Respiratory gas analysis during exercise as a noninvasive measure of lactate concentration in chronic congestive heart failure. Am J Cardiol. 1983;51:1639-43.

49. Arena R, Myers J, Williams MA, Gulati M, Kligfield P, Balady GJ, et al. Assessment of functional capacity in clinical and research settings: a scientific statement from the American Heart Association Committee on Exercise, Rehabilitation, and Prevention of the Council on Clinical Cardiology and the Council on Cardiovascular Nursing. Circulation. 2007;116:329-43.

50. Myers J. Information from ventilatory gas exchange data. In: Washburn R, editor. Essentials of cardiopulmonary exercise testing. Champaign: Human Kinetics; 1996. p. 83-108.

51. Gitt AK, Wasserman K, Kilkowski C, Kleemann T, Kilkowski A, Bangert M, et al. Exercise anaerobic threshold and ventilatory efficiency identify heart failure patients for high risk of early death. Circulation. 2002;106:3079-84.

52. Uren NG, Davies SW, Agnew JE, Irwin AG, Jordan SL, Hilson AJ, etal. Reduction of mismatch of global ventilation and perfusion on exercise is related to exercise capacity in chronic heart failure. Br Heart J. 1993;70:241-6.

53. Wada 0 , Asanoi $H$, Miyagi $K$, Ishizaka $S$, Kameyama $T$, Seto $H$, et al. Importance of abnormal lung perfusion in excessive exercise ventilation in chronic heart failure. Am Heart J. 1993;125:790-8.

54. Ponikowski P, Francis DP, Piepoli MF, Davies LC, Chua TP, Davos CH, et al. Enhanced ventilatory response to exercise in patients with chronic heart failure and preserved exercise tolerance: marker of abnormal cardiorespiratory reflex control and predictor of poor prognosis. Circulation. 2001;103:967-72.

55. Chua TP, Clark AL, Amadi AA. The relationship between chemosensitivity and the ventilatory response to exercise in chronic heart failure. J Am Coll Cardiol. 1996; 27:650-7.

56. Piepoli M, Clark AL, Volterrani M. Contribution of Muscle Affarents to the Hemodynamic, Autonomic, and Ventilatory Responses to Exercise in Patients with Chronic Heart Failure. Circulation. 1996; 93:940-52.

57. Sullivan MJ, Higginbotham MB, Cobb FR. Increased exercise ventilation in patients with chronic heart failure: intact ventilatory control despite hemodynamic and pulmonary abnormalities. Circulation. 1988; 77:552-9.
58. Guazzi M, Reina G, Tumminello G, Guazzi MD. Alveolar-capillary membrane conductance is the best pulmonary function correlate of exercise ventilation efficiency in heart failure patients. Eur J Heart Fail. $2005 ; 7: 1017-22$.

59. Francis DP, Shamim W, Davies LC, Piepoli MF, Ponikowski P, Anker SD, et al. Cardiopulmonary exercise testing for prognosis in chronic heart failure: continuous and independent prognostic value from VE/VCO(2) slope and peak V0(2). Eur Heart J. 2000; 21:154-61.

60. Kleber FX, Vietzke G, Wernecke KD, Bauer U, Opitz C, Wensel R, et al. Impairment of ventilatory efficiency in heart failure: prognostic impact. Circulation. 2000;101:2803-9.

61. Bard RL, Gillespie BW, Clarke NS, Egan TG, Nicklas JM. Determining the best ventilatory efficiency measure to predict mortality in patients with heart failure. Heart Lung Transplant. 2006; 25:589-95.

62. Arena R, Myers J, Guazzi M. The clinical and research applications of aerobic capacity and ventilatory efficiency in heart failure: an evidencebased review. Heart Fail Rev. In press 2007.

63. Arena R, Myers J, Aslam S, Varughese EB, Peberdy MA. Technical considerations related to the minute ventilation/carbon dioxide output slope in patients with heart failure. Chest. 2003;124:720-7.

64. Ribeiro JP, Knutzen A, Rocco MB, Hartley LH, Colucci WS. Periodic breathing during exercise in severe heart failure. Reversal with milrinone or cardiac transplantation. Chest. 1987;92:555-6.

65. Feld $H$, Priest $S$. A cyclic breathing pattern in patients with poor left ventricular function and compensated heart failure: a mild form of CheyneStokes respiration? J Am Coll Cardiol. 1993; 21:971-4.

66. Corra U, Pistono M, Mezzani A, Braghiroli A, Giordano A, Lanfranch $P$, et al. Sleep and exertional periodic breathing in chronic heart failure: prognostic importance and interdependence. Circulation. 2006;113:44-50.

67. Corra U, Giordano A, Bosimini E, Mezzani A, Piepoli M, Coats AJ, et al. Oscillatory ventilation during exercise in patients with chronic heart failure: clinical correlates and prognostic implications. Chest. 2002; 121:1572-80.

68. Lahiri S, Hsiao C, Zhang R, Mokashi A, Nishino T. Peripheral chemoreceptors in respiratory oscillations. J Appl Physiol. 1985; 58:1901-8.

69. Yajima T, Koike A, Sugimoto K, Miyahara Y, Marumo F, Hiroe M. Mechanism of periodic breathing in patients with cardiovascular disease. Chest. 1994;106:142-6.

70. Francis DP, Willson K, Davies LC, Coats AJ, Piepoli M. Quantitative general theory for periodic breathing in chronic heart failure and its clinical implications. Circulation. 2000;102:2214-21.

71. Guazzi M, Raimondo R, Vicenzi M, Arena R, Proserpio C, Sarzi BS, et al. Exercise oscillatory ventilation may predict sudden cardiac death in heart failure patients. J Am Coll Cardiol. 2007;50:299-308.

72. Guazzi M, Arena R, Ascione A, Piepoli M, Guazzi MD. Exercise oscillatory breathing and increased ventilation to carbon dioxide production slope in heart failure: an unfavorable combination with high prognostic value. Am Heart J. 2007;153:859-67. 
73. Arena R, Myers J, Hsu L, Peberdy MA, Pinkstaff S, Bensimhon D, et al. The minute ventilation/carbon dioxide production slope is prognostically superior to the oxygen uptake efficiency slope. J Card Fail. 2007;13:462-9.

74. Davies LC, Wensel R, Georgiadou P, Cicoira M, Coats AJ, Piepoli MF, et al. Enhanced prognostic value from cardiopulmonary exercise testing in chronic heart failure by non-linear analysis: oxygen uptake efficiency slope. Eur Heart J. 2006;27:684-90.

75. Arena R, Peberdy MA, Myers J, Guazzi M, Tevald M. Prognostic value of resting end-tidal carbon dioxide in patients with heart failure. Int J Cardiol. 2006; 109:351-8.

76. Arena R, Guazzi M, Myers J. Prognostic value of end-tidal carbon dioxide during exercise testing in heart failure. Int J Cardiol. 2007; 117:103-8.

77. Arena R, Guazzi M, Myers J, Peberdy MA. Prognostic value of heart rate recovery in patients with heart failure. Am Heart J. 2006;151:851.

78. Lipinski MJ, Vetrovec GW, Gorelik D, Froelicher VF. The importance of heart rate recovery in patients with heart failure or left ventricular systolic dysfunction. J Card Fail. 2005;11:624-30.

79. Sheppard RJ, Racine N, Roof A, Ducharme A, Blanchet M, White M. Heart rate recovery - a potential marker of clinical outcomes in heart failure patients receiving beta-blocker therapy. Can J Cardiol. 2007; 23:1135-8.

80. Van Laethem C, Van De Veire N, Backer GD, Bihija S, Seghers T, Cambier $D$, et al. Response of the oxygen uptake efficiency slope to exercise training in patients with chronic heart failure. Eur J Heart Fail. 2007;9:625-9.

81. Myers J, Hadley D, Oswald U, Bruner K, Kottman W, Hsu L, et al. Effects of exercise training on heart rate recovery in patients with chronic heart failure. Am Heart J. 2007;153:1056-63.

82. Froelicher V, Morrow K, Brown M, Atwood E, Morris C. Prediction of atherosclerotic cardiovascular death in men using a prognostic score. Am J Cardiol. 1994; 73:133-8.

83. Morris CK, Morrow K, Froelicher VF, Hideg A, Hunter D, Kawaguchi T, et al. Prediction of cardiovascular death by means of clinical and exercise test variables in patients selected for cardiac catheterization. Am Heart J. 1993:125:1717-26
84. Dubach P, Froelicher VF, Klein J, Oakes D, Grover-McKay M, Friis R. Exercise-induced hypotension in a male population. Criteria, causes, and prognosis. Circulation. 1988; 78:1380-7.

85. Morrow K, Morris CK, Froelicher VF, Hideg A, Hunter D, Johnson $E$, et al. Prediction of cardiovascular death in men undergoing noninvasive evaluation for coronary artery disease. Ann Intern Med. 1993;118:689-95.

86. Mezzani A, Corra U, Giannuzzi P. Central adaptations to exercise training in patients with chronic heart failure. Heart Fail Rev. 2008;13:13-20.

87. Haykowsky MJ, Liang Y, Pechter D, Jones LW, McAlister FA, Clark AM A Meta-Analysis of the effect of exercise training on left ventricular remodeling in heart failure patients: The benefit depends on the type of training performed. J Am Coll Cardiol. 2007;49:2329-36.

88. Whellan DJ, O'Connor CM, Lee KL, Keteyian SJ, Cooper LS, Ellis $\mathrm{SJ}$, et al. Heart failure and a controlled trial investigating outcomes of exercise training (HF-ACTION): Design and rationale. Am Heart J. 2007;153:201-11.

89. Smart N, Haluska B, Jeffriess L, Marwick TH. Exercise training in systolic and diastolic dysfunction: Effects on cardiac function, functional capacity, and quality of life. Am Heart J. 2007;153:530-6.

90. Braith R, Beck D. Resistance exercise: training adaptations and developing a safe exercise prescription. Heart Fail Rev. 2008;13:69-79.

91. Quittan M, Wiesinger GF, Sturm B, Puig S, Mayr W, Sochor A, et al Improvement of thigh muscles by neuromuscular electrical stimulation in patients with refractory heart failure: a single-blind, randomized, controlled trial. Am J Phys Med Rehabil. 2001; 80:206-14.

92. Nuhr MJ, Pette D, Berger R, Quittan M, Crevenna R, Huelsman M, et al. Beneficial effects of chronic low-frequency stimulation of thigh muscles in patients with advanced chronic heart failure. Eur Heart J. 2004;25:136-43.

93. Deley G, Kervio G, Verges B, Hannequin A, Petitdant MF, Salmi-Belmihoub $S$, et al. Comparison of low-frequency electrical myostimulation and conventional aerobic exercise training in patients with chronic heart failure. Eur J Cardiovasc Prev Rehabil. 2005;12:226-33. 